\title{
Our Sustainable Future
}

The series Our Sustainable Future provides an interdisciplinary forum for discussion of issues bearing on the development of sustainable communities and resource bases at both the local and the global levels.

\section{Building Soils for Better Crops Organic Matter Management}

\section{Fred Magdoff}

Written for farmers, gardeners, extension specialists, and others interested in the practical stewardship of our natural resources, Building Soils for Better Crops presents the latest information on soil organic matter and explains modem management techniques along with the best of the older practices. Fred Magdoff discusses the nature of organic matter and its function in the soil and reviews practices for building up and maintaining soil organic matter, including strategies for reduced tillage, residue management, and crop rotations.

$\$ 22.95$

\section{Agricultural Research Alternatives}

\section{William Lockeretz and Molly D. Anderson}

Available in October $\$ 30.00$

\section{Ogallala Water for a Dry Land John Opie}

"Extremely important and timely as a case study not only in the complex variables affecting the relationship between farmers and groundwater, but also as a blueprint for the future of the region."-Donald E. Green, Central State University, Oklahoma.

Focusing on the Ogallala aquifer, John Opie vividly portrays the south-central plains-its natural resources, the history of settlement and dryland farming, and the remarkable irrigation technologies that have industrialized farming in the region.

$\$ 35.00$

\section{Crop Improvement for Sustainable Agriculture}

Edited by M. Brett Callaway and Charles A. Francis

Available in November $\$ 35.00$

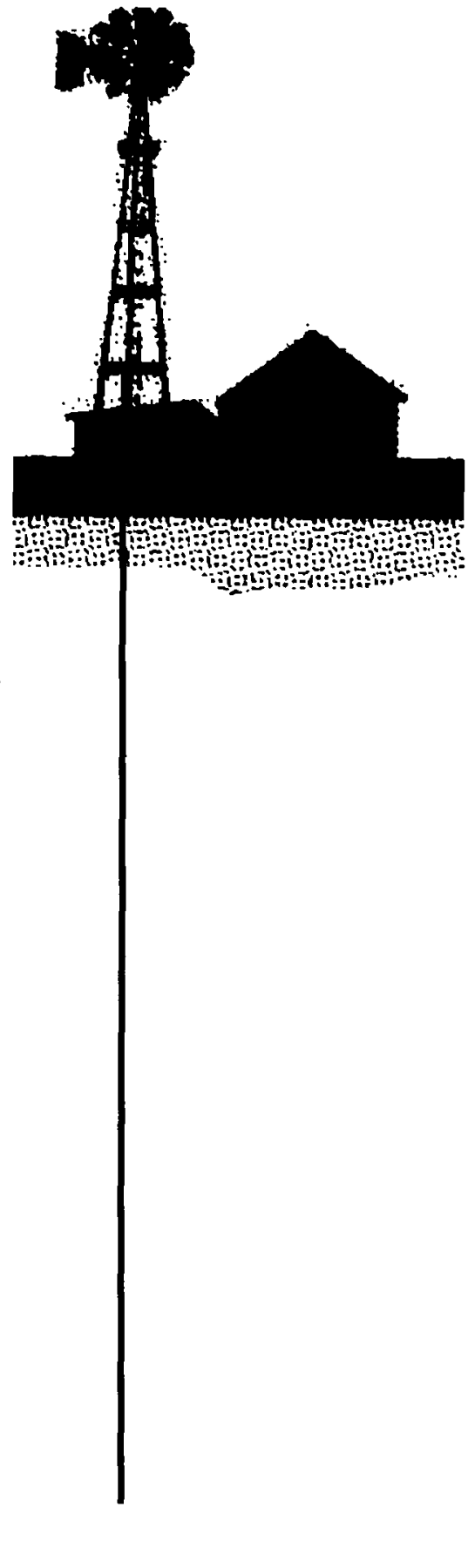


Back volumes. Inquiries for Vols, 1-32 of The Empire. Joumal of Experimental Agriculture should be addressed to Wm Dawson \& Sons Ltd, Cannon House, Folkestone, Kent. Previously published parts of Experimental Agricultue are available from Cambridge or the American Branch of Cambridge University Press.

Preparation and submission of manuscripts. Detailed instructions on the preparation of manuscripts are printed at the back of the first number of each volume of this journal.

Potential contributors are asked to give careful attention to these instructions. This will greatly assist the editors and thus speed the processing of their contributions.

Copying. This journal is registered with the Copyright Clearance Center, 27 Congress St., Salem, Mass, 01970. Organizations in the USA who are also registered with C.C.C. may therefore copy material beyond the limits permitted by sections 107 and 108 of US copyright law) subject to payment to C.C.C. of the per copy fee of $\$ 5.00$. This consent does not extend to multiple copying for promotional or commercial purposes. Code 0014-4797/93 \$5.00+3.00.

ISI Tear Sheet Service. 3501 Market Street, Philadelphia, Pennsylvania 19104, USA, is authorized to supply single copies of separate articles for private use only.

Organizations authorized by the Copyright Licensing Agency may also copy material subject. to the usual conditions.

For all other use, permission should be sought from Cambridge or the American Branch of Cambridge University Press.

\section{CAMBRIDGE UNIVERSITY PRESS}

The Pitt Building, Trumpington Street, Cambridge CB2 IRP

40 West 20th Sureet, New York, NY 10011 -4211, USA

10 Stamford Road, Oakleigh, Melbourne 3166, Australia

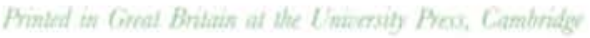




\section{Experimental Agriculture}

\section{CONTENTS}

R. J. Summerfield, R. J. Lawn, A. Qi, R. H. Ellis, E. H. Roberts, P. M. Chay, J. B. Brouwer, J. L. Rose, S. Shanmugasundaram, S. J. Yeates and S. Sandover: Towards the Reliable Prediction of Time to Flowering in Six Annual Crops. II. Soyabean (Glycine max)

B. Gail Smith, William Stephens, Paul J. Burgess and M. K. V. Carr: Effects of Light, Temperature, Irrigation and Fertilizer on Photosynthetic Rate in Tea (Camellia sinensis)

N. H. Nam, Y. S. Chauhan and C. Johansen: Comparison of Extrashort-duration Pigeonpea with Short-season Legumes under Rainfed Conditions on Alfisols

A. Larbi, M. A. Jabbar, A. N. Atta-Krah and J. Cobbina: Effect of Taking a Fodder Grop on Maize Grain Yield and Soil Chemical Properties in Leucaena and Gliricidia Alley Farming Systems in Western Nigeria

William Stephens and M. K. V. Carr: Responses of Tea (Camellia sinensis) to Irrigation and Fertilizer. III. Shoot Extension and Development

H. O. Odhiambo, J. O. Nyabundi and J. Chweya: Effects of Soil Moisture and Vapour Pressure Deficits on Shoot Growth and the Yield of Tea in the Kenya Highlands

J. K. Itabari, P. J. Gregory and R. K. Jones: Effects of Temperature, Soil Water Status and Depth of Planting on Germination and Emergence of Maize (Zea mays) Adapted to Semi-arid Eastern Kenya

B. A. Ruhigwa, M. P. Gichuru, N. M. Tariah, N. O. Isirimah and D. C. Douglas: Spatial Variability in Soil Chemical Properties under Dactyladenia barteri, Alchomea cordifalia, Senna siamea and Gmelina arborea Hedgerows on an Acid Ultisol

J. M. Njoroge, K. Waithaka and J. A. Chweya: Effects of Intercropping Young Plants of the Compact Arabica Coffec Hybrid Cultivar Ruiru 11 with Potatoes, Tomatoes, Beans and Maize on Coffee Yields and Economic Returns in Kenya

W. Grisley and Moffat Shamambo: An Analysis of the Adoption and Diffusion of Carioca Beans in Zambia Resulting from an Experimental Distribution of Seed

Book Reviews 